\title{
THE BACKGROUND
}

\author{
GLEN W. ACORN* \\ INTRODUCTORY
}

This Research Seminar is devoted to constitutional problems in the Canadian oil and gas industry largely with respect to two subject matters; firstly, pipe lines and secondly, regulation of oil and gas as commodities. The problems arise from the division of legislative power contained in Canada's constitutional document, the British North America Act, 1867. The purpose of this paper is to set the stage for the papers which follow. Primarily its object is to indicate the sources of jurisdiction of Parliament and of the provinces, to show the extent to which the respective governments have legislated, to examine some of the more significant cases which directly involve these subject matters, to compare the Canadian problem with that in the United States and, finally to pose the questions for the other speakers to answer.'

As to legislation, no attempt is made to indicate that any given statute or regulation is beyond the powers of the body which made it. Succeeding speakers will be propounding the federal viewpoint and the provincial viewpoint. In this paper it will be sufficient to attempt an objective picture of things as they are, avoiding any appearance of favouring one viewpoint over the other.

\section{SOURCES OF LEGISLATIVE POWER}

Sections 91 and 92 of the British North America Act, 1867, are the key provisions which distribute legislative powers between the Parliament of Canada and the Legislatures of the Provinces. In this Seminar attention will be focussed on the following portions of those provisions:

\section{"VI. DISTRIBUTION OF LEGISLATIVE POWERS}

\section{Powers of the Parliament.}

91. It shall be lawful for the Queen, by and with the Advice and Consent of the Sennte and House of Commons, to make laws for the Peace, Order, and good Government of Canada, in relation to all Matters not coming within the Classes of Subjects by this Act assigned exclusively to the Legislatures of the Provinces; and for greater Certainty, but not so as to restrict the Generality of the foregoing Terms in this Section, it is hereby declared that (notwithstanding anything in this Act) the exclusive Legislative Authority of the Parliament of Canada extends to all Matters coming within the Classes of Subjects next hereinafter enumerated; that is to say,-

2. The Regulation of Trade and Commerce.

29. Such Classes of Subjects as are expressly excepted in the Enumeration of the Classes of Subjects by this Act assigned exclusively to the Legislatures of the Provinces.

And any Matter coming within any of the Classes of Subjects enumerated in this Section shall not be deemed to come within the Class of Matters of a local or private Nature comprised in the Enumeration of the Classes of Subjects by this Act assigned exclusively to the Legislatures of the Provinces.

-Glen W. Acorn. then Solicitor. Department of Mines and Minerals, now Assistant Legislative Counsel. Department of the Attomey-General, Province of Aiberta.

1 The Edmonton lawyers composed a seminar group on this toplc and gave valuable advice and criteism in the preparation of the paper. Some made contributlons to the text which are acknowledeed in the appropriate places. 


\section{Exclusives Powers of Provincial Legislatures}

92. In each Province the Legislature may exclusively make Laws in relation to matters coming within the Classes of Subjects next hereinafter enumerated; that is to say,-

10. Local Works and Undertakings other than such as are of the following Classes:

(a) Lines of Stcam or other Ships, Railways, Canals, Telegraphs, and other Works and Undertakings connecting the Province with any other or others of the Provinces, or extending beyond the Limits of the Province:

(c) Such Works as, although wholly situate within the Province, are before or after their Execution declared by the Parliament of Canada to be for the general Advantage of Canada or for the Advantage of Two or more of the Provinces.

13. Property and Civil Rights in the Province.

16. Generally all Matters of a merely local or private Nature in the Province."

Parliament's power to legislate in relation to extra-provincial pipe lines stems in the main from Head 29 of section 91 which, in turn, refers to the exception in clause (a) of Head 10 of section 92: "other Works and Undertakings connecting the Province with any other or others of the Provinces, or extending beyond the Limits of the Provinces:" Its power to legislate in relation to prorationing and pricing of oil and gas finds its main source in Head 2 of section 92: "The Regulation of Trade and Commerce."

The Province's powers to legislate in relation to all of these fields stem from section 92 and in particular Heads 10,13 and 16 quoted above. These provisions have given rise to the majority of the approximately two hundred cases in the Judicial Committee of the Privy Council spanning a period of eighty years, and, of course, to a great many other decisions in the Supreme Court of Canada and provincial courts. One of the problems which confronts this Seminar is the somewhat remarkable fact that there is a complete dearth of constitutional cases specifically dealing with pipe lines or oil and gas. As to proprationing and pricing, there is not a single decision, and respecting pipe lines there seems to be only one case in the Supreme Court of Canada and one in a county court in British Columbia.

Those who would study this problem must satisfy themselves with decisions which provide analogies. As to pipe lines, they have their choice of railways, ${ }^{2}$ telephones, ${ }^{3}$ electric power lines, ${ }^{4}$ radio $^{5}$ and bus lines. ${ }^{6}$ As to oil and gas as commodities, they have their choice of sheep, swine, ${ }^{7}$ hogs, peaches, ${ }^{8}$ potatoes, ${ }^{0}$ dairy products $^{10}$ - just name it; what-

2 C.P.R. v. Bonsecours, [1899] A.C. 367; Madden v. Neleon and Fort Sheppard Ry. [1899] A.C. 626; G.T.R. Y. A.C. for Canada, (1906] A.C. 65; A.-G. for B.C. V. C.P.R., [1906) A.C. 204; Toronto v. C.P.R. [1908] A.C.'S4; Toronto Ry. v. Toronto, [1920] A.C.' 426; Luscer Collieries Ltd. v. MeDonald, [1927] A.C. 925; Canadian Electrical Assoctation v. C.N.R., [1934] A.C. 551; C.P.R. V.A.-G. for B.C., [1950] A.C. 122; A.-G. for Canada v. C.P.R. [1958] S.C.R. 283.

a Toronio v. Bell Telephone Co., [1905] A.C. 52.

4 Newson v. Onterio Power Co., [1905] 36 S.C.R. 596; Ottawa Valley Potoer Co. v. A.-G. for Ontario, [1936] \& D.L.R. 594.

Ontario, [1936] 4 D.L.R. 594 .

B A.-G. Ror Ontario v. Winner, [1954] A.C. $\$ 41$; also reported as S.M.T. (Eastern) Ltd. v. Winner and A.-G. for Ontario, [1954] 13 W.W.R. (N.S.) 657 .

I Re Sheep and Swine Marketing Scheme, (194i] 3 D.L.R. 569.

8 Rejerence re The Farm Products Aarketing Act, [1957] S.C.R. 198, 7 D.L.R. (d) 257.

- P.E.I. Potato Marketing Board v. H.B. Willts inc., [1952] 2 8.C.R. 392.

10 Shannon v. Lower Mainland Dairy Products Board, [1938] \& D.L.R. 81; Reference re Valtdity of Soction 5 (a) of the Dairy Industry Act, [1940] I D.L.R. 433. 
ever the choice, it will, generally speaking, ${ }^{11}$, be animal or vegetablebut not mineral. As will be seen in this and the other papers, however some of these analogies are neat and appropriate. ${ }^{12}$

\section{PIPE LINES}

\section{Provincial Legislation}

Each of the five provinces has statutes which deal with the construction and operation of pipe lines in considerable detail. ${ }^{13}$ They may be summarized readily by pointing out the following basic features common to all of them:

The requirement for permission from the government or an agency of the government before a pipe line can be constructed.

Powers of expropriation.

The requirement for permission from the government or an agency of the government before the pipe line may be operated.

For our purpose the only point of interest is that in the case of the Acts of the three Prairie Provinces, the respective Legislatures have used language intended to confine the operation of the statute to pipe lines within provincial jurisdiction although the mode of expression in each case is somewhat different.

In Manitoba, the two pipe line statutes are declared to apply only to pipe lines situated "wholly within the province"."

In Saskatchewan, the Act states that it "is intended to operate only as to matters that are within the exclusive legislative jurisdiction of the province". 10

Alberta has attempted to draw a more precise line; its statute says that it applies to all pipe lines in the province excepting

"(b) a pipe line for which there is in force

(i) a certificate, or

(ii) an order exempting the pipe line from a certificate,

issued or made by the National Energy Board under the National Energy Board Act (Canada)."10

Special mention should be made of The Alberta Gas Trunk Line Company Act, enacted by the Alberta legislature in $1954^{17}$, because the Alberta Gas Trunk Line will likely be cited repeatedly at this Seminar as the most obvious and cogent illustration of the problems of jurisdiction. Here again, the Legislature has taken care to show that the Act is confined to matters of provincial concern. ${ }^{18}$ On its face, however, the Act does not disclose how vital an instrument it is in the Province's gas policy.

11 The lone exceptlons are Spooner Olls Led. v. Turner Valley Ges Conservation Board, [1933] S.C.R. 629. reversins [1932] 2 W.W.R. 477 (but afflming the Appellate Diviston on the Trade and Commerce clause); and Home Oil Distributors Ltd. v. A.-G. for B.C., [1940] S.C.R. 444.

12 See lootnote 74 , post.

13 B.C.: Plpe-Lines Act, R.S.B.C. 1960, c. 284: Alberta: The Plpe Line Act, 1958, Alta., 1958, c.58; Saskatchewan. The Plpe Lines Act, Sask., 1954, c.83; Manitoba: The Pipe Llne Act, Man 1954, c.26 (oil and water), and the Gas Pipe Line Act, Man., 1956, c.27; Ontarlo: The EnerEy Act. R.S.O. 1960, c.122.

14 Man., 1954, c.26, $3.3(2)$ and Man., 1956, c.27, $s .2(2)$.

16 Sask., 1934, c.83, 3.4.

26 Alta. 1958, c.5B, s.3(b).

it Alta., 1954, c.37.

is Ibid, s. 18 (I) and 14. 
It is common knowledge that since 1954 the Alberta Gas Trunk Line Company Limited has been given an almost exclusive status as the builder and operator of the gas grid system in Alberta, and that deliveries of gas to the Alberta terminals of extra-provincial pipe lines are made only through the facilities of the company. ${ }^{10}$ This status has been conferred by the government through administration of The Pipe Line Act, $1958^{20}$, The Oil and Gas Conservation Act ${ }^{21}$, and The Gas Resources Preservation Act, 1956"2, and the predecessors of these statutes.

Presently, Alberta Gas Trunk operates pipe lines that deliver gas to the terminals of four "Special Act companies"-to Trans-Canada Pipe Line Company Limited at a point near the Saskatchewan border for consumption in Eastern Canada and the United States; to Alberta Natural Gas Pipe Line Company Limited at a point near the British Columbia boundary in the Crows Nest Pass for delivery to a major market in California; to Canadian-Montana Gas Company Limited at a point near the Montana border to serve consumers in that State; ${ }^{23}$ and to Westcoast Transmission Company Limited at a northerly point near the British Columbia border for consumption in that Province and the Pacific Northwest. Alberta Gas Trunk acts as a transmitter only of the gas. The gas transmitted is the property of the company that has purchased it from the producers, and the Special Act company is the purchaser in each case, except that gas delivered to the Alberta Natural Gas Pipe Line Company is the property of an affiliate, Alberta and Southern Gas Company Limited. In each case, the custody of the gas is transferred to the Special Act company at a point within Alberta because Alberta Gas Trunk is prohibited from acquiring property outside the Province. ${ }^{24}$

These brief comments more or less exhaust the subject of provincial legislation respecting pipe lines. One observes that on the surface these statutes are unenlightening so far as the problems of this seminar are concerned.

Federal legislation on the other hand is much more revealing as to Parliament's and the Federal Government's intentions, and thus deserves a more complete discussion.

\section{Federal Legislation ${ }^{23}$}

(a) The Pipe Lines Act and Its Predecessors.

The Federal Government first entered the pipe line field in 1907 with the enactment of the Electricity and Fluid Exportation Act ${ }^{26}$, a short Act

10 There are presently four pipe llnes removing gas from Alberta in whlch Alberta Gas Trunk is not involved: 1. P. T. Buckley exports gas by a line 10 miles north of the U.S. boundary to a point near Springbank. Montana (export originally commenced in 1935: 2. Westcoast Transmlssion Company Limited takes delivery from Its Alberta subsidlary of gas from flelds in northwestern Alberta; 3. Canadlan-Montana Gas Company Limlted Eathers and carrles gas from fields In gouth-eastern Alberta across the U.S. pany Limited Bather and cares Aforta

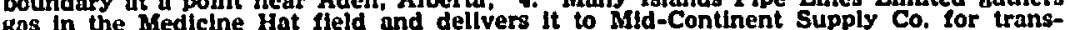
mlssion across the Alberta-Saskatchewan boundary to the facilities of the Saskatchewan mission across the A

20 Alta., 1958, c.58.

21 Alta., 1957, c.63.

Alta., 1956; c.19.

23 This reference is to Canadjan-Montana's second outlet south of Cardston, Alberta, and some 90 miles west of that mentloned in footnote 19 .

24 Alta. 1954, c.37.

25 Ala., 1954, c.37. National Enerty Board, Ottawa, in supplying much of the backeround and factual material for this section.

20 Can., 1907, c. 16; R.s.C. 1927, c.54; R.s.C. 1952, c.93. 
consisting of ten sections of which only two brief provisions were devoted to international pipe lines. The Act simply authorized the Government to grant a licence for the construction of an international pipe line for the exportation of petroleum or natural gas, and prohibited such construction without a licence.

Rather curiously, this Act remained in force unchanged (apart from a minor amendment in 1950) until it was repealed in 1955 when it was replaced by the Exportation of Power and Fluids and Importation of Gas Act ${ }^{27}$, which in turn omitted all reference to pipe lines. Also curious was the fact that over twenty years passed before a licence to construct an international pipe line was granted under the 1907 Act. On April 30, 1930, a licence was granted to Range Oil and Gas Company Limited to construct a pipe line from the location of a well known as the Rogers Imperial well in legal subdivision 9 of section 29, township 1, range 11, west of the 4th meridian for a distance of some thirty miles to a point at the Alberta - Montana boundary west of Aden, Alberta. (This same company was taking no chances on being involved in any constitutional hiatus as it also obtained a permit for exactly the same pipe line under The Pipe Line Act of Alberta on September 2, 1930. The line was discontinued and taken up around 1941.)

It was not until 1949 that Parliament legislated with respect to interprovincial pipe lines with the enactment of the Pipe Lines Act ${ }^{28}$. (It also applied to international pipe lines and to that extent was an overlapping of the Electricity and Fluid Exportation Act.) The Pipe Lines Act regulated and gave certain powers, including expropriation powers, to "Special Act companies", that is, companies incorporated under Acts of Parliament specifically authorizing named companies to construct or operate oil or gas pipe lines. The Act was administered by the Board of Transport Commissioners for Canada. While it appeared that only Special Act companies could take the benefit of the Pipe Lines Act, it later appeared that if any company did not require expropriation powers in order to complete an interprovincial pipe line, it might do so without obtaining a Special Act of Parliament or leave of the Board of Transport Commissioners to construct or operate. Such a company in no way offended the Act. This "loophole", if you like, was closed by an amendment passed on December 16, $1953^{20}$ wherein Parliament added a definition of "extra-provincial pipe line" and a new section prohibiting any person other than a Special Act company from constructing or operating an extra-provincial pipe line. By this amendment Parliament thus asserted strict control over all interprovincial and international pipe lines.

Following the report of the Royal Commission on Energy (the Borden Commission) Parliament enacted the National Energy Board Act which replaced the Pipe Lines Act and the Exportation of Power and Fluids and Importation of Gas Act. 


\section{(b). The National Energy Board Act}

The National Energy Board Act ${ }^{30}$ established a five-member Board which assumed the functions of the Board of Transport Commissioners under the former Acts, except that those functions were considerably enlarged. Confining discussion for the time being to pipe lines only, the Act contains the basic features of most pipe line statutes-

The requirement for a Certificate of Public Convenience and Necessity before a pipe line can be constructed.

Powers of expropriation.

The requirement to obtain leave of the Board before the commencement of operation.

Regulation of traffic, tolls and tariffs.

Like its predecessors, the Act provides that only Special Act companies are permitted to construct or operate extra-provincial pipe lines. It should be noted, however, that under section 49 the Board may exempt a pipe line or a branch or extension of a pipe line, not more than twenty-five miles long, from any or all of the provisions of sections 25 to 29. In fact, the Board has on about twenty-four occasions granted exemption orders under section 49 , but in the main they relate to pumping and compressor facilities and loops, and relieve Special Act companies from the requirement for a Certificate of Public Convenience and Necessity and a formal hearing. An exemption order was granted by the Board of Transport Commissioners under the equivalent section in the Pipe Lines Act whereby a company other than a Special Act company was allowed to construct an international pipe line to serve the community of Coutts, Alberta, with gas from Montana. It is possible that the present Board would grant exemptions in similar cases or cases of a minor nature in which no great matter of public interest is involved.

With reference to the constitutional problem, this seminar will be interested particularly in the following provisions of the Act and regulations:

(i) The definition of "pipe line" in section $2(\mathrm{~m})$ uses the precise language in Head 10 (a) of section 92 of The British North America Act and reads:

"(m) 'Pipe line' means a line for the transmission of hydrocarbons connecting a province with any other or others of the provinces, or extending beyond the limits of a.province, and includes all branches, extensions, tanks, reservoirs, pumps, racks, compressors, loading facilities, interstate systems of communication by telephone, telegraph or radio, and real and personal property and works connected therewith".

(ii) Section 79 of the Act permits certain provincial legislation to apply to the undertaking of Special Act companies and reads:

"79. It is hereby declared

(a) that nothing in this Act restricts or prohibits any of the following transactions, namely,

(i) the sale under execution of any property of a company, or

(ii) the creation of any lien, mortgage, charge or other security on the property of the company, or the sale, pursuant to an order of a court, of any property of the company to enforce or realize on any such lien, mortgage, charge or other security; and

30 Can., 1959, c.46, alnee amended by Can., 1960, c.9; and Can., 1961-62, c.52. 
(b) that a transaction mentioned in paragraph (a) in respect of any property of the company is subject to the same laws to which it would be subject if the work and undertaking of the company were a local work or undertaking in the province in which that property is situated."

This section appeared for the first time in the National Energy Board Act and, so far as mechanics liens are concerned, reverses the result in the Comstock case (to be discussed later) which held that a provincial mechanics lien Act could not apply to an undertaking within the exclusive jurisdiction of Parliament.

(iii) The National Energy Board Rules of Practice and Procedure ${ }^{31}$ require an applicant for a certificate in respect of a gas pipe line to file the information set out in Part I of the Schedule to the regulations: Item (16) requires the applicant to show

"(16) where authorization for the removal of gas from the province in which it is produced is required by a statute of the province, evidence of having obtained the authorization from the provincial authority for the removal of gas produced from those pools, fields or areas within the province referred to in clause (4) and in the quantities shown in the deliverability schedule referred to in clause (6) as available from such pools, fields or areas."

This requirement obviously is a tacit reference in particular to The Gas Resources Preservation Act, 1956 of Alberta $^{32}$ which prohibits removal of gas from Alberta without a permit.

\section{The Cases ${ }^{3 s}$}

As indicated earlier there are but few cases in which a constitutional issue has arisen in relation to pipe lines, and they can be quite readily reviewed.

The case of Campbell-Bennett Ltd. v. Comstock Mid-Western Ltd..$^{34}$, the sole case in the Supreme Court of Canada, involved Comstock MidWestern Ltd., a pipe line construction company that encountered financial difficulties during the construction of the Trans Mountain Oil Pipe Line. The pipe line extended from Alberta to British Columbia, and the issue was whether the company was affected by the claims of persons asserting lien rights conferred upon them by a provincial legislature.

The British Columbia Court of Appeal held that proceedings to enforce a lien under the Mechanic's Lien Act of that province could not be taken against a company incorporated by special Act of the Dominion in its operations of an interprovincial pipe line. The basis for the decision is indicated in the judgment of Mr. Justic O'Halloran at page 685 in these terms:

"Once it appears the interprovincial oil pipe line comes exclusively within Dominion jurisdiction, it must follow that no agency of provincial origin and authority can interfere with, hamper or destroy the oil pipe line undertaking. To enforce a mechanics' lien, sale must take place of thrt portion within the jurisdiction of the county wherein the county court declares the mechanics' lien to exist. The consequences of such sale of a segment by provincial authority, if it could be permitted, would lead obviously to disruption, disintegration and destruction of the whole, not only as a physically continuous interprovincial oll pipe line, but also as a great Dominion undertaking. In short,

81 These Rules are not filed under the Regulations Act and thus do not appear in the Canada Gazette. They are printed by the Queen's Printer, Ottawa, as part of an office consolidation of the Act and regulations thereunder.

82 See footnote 22 , ante. 93 The author thanks Mr. A. J. Cressey of Edmonton for his help in the preparation of

34 (1954), 3 D.L.R. 481, [1954] 8.C.R. 207, affirming (1933), 8 W.W.R. (N.S.) 683. 
the jurisdiction of the province could then be invoked to obstruct and defeat an undertaking completely outside its jurisdiction, and solely within the jurisdiction of the Dominion."

The Supreme Court of Canada appeared to have little difficulty in upholding the decision unanimously and, in view of the decided cases, the result was not surprising.

In Cant v. Canadian Bechtel Ltd. ${ }^{\text {ss }}$ Boyd, C.C.J., following the Comstock case in dismissing a claim for overtime pay, held that The Male Minimum Wage Act of British Columbia did not apply to the undertaking of Trans Mountain Oil Pipe Line Company.

These cases are the only court decisions. In addition there are three decisions of the Board of Transport Commissioners which merit examination.

In Trans-Northern Pipe Line Co. v. A.-G. of Quebec et al so, the Board, in dealing with an attack on the constitutionality of the Pipe Lines Act of Canada, held, following previous Board decisions, that it was not "the function of this Board to pass upon the constitutionality or validity of legislation whether Dominion or Provincial". In the same case certain municipalities objected to possible hazards from the pipe line and insisted that a condition of the authorization should be that all local municipal by-laws should be observed by the pipe line company. The Board rejected the contention, holding that Parliament had conferred upon the Board jurisdiction over the construction of the pipe line, and that it would not be proper to transfer part of that jurisdiction to a municipality.

The other two cases before the Board were the famous "Westspur cases".

Westspur Pipe Line Company is a Special Act company owning oil flow lines, gathering systems and trunk lines in South Eastern Saskatchewan. The company gathers the oil from the producing wells and batteries, and transports it via an interprovincial trunk line to the Interprovincial Pipe Line Co. terminal at Cromer, Manitoba.

In Re Westspur Pipe Line Co. Extension ${ }^{37}$, decided on December 3, 1956, Westspur requested permission to build an extension of its oil pipe line westward from its terminal at Midale, Saskatchewan. The application was opposed by the Province of Saskatchewan and by Trans-Prairie Pipelines Ltd., a provincial company. Trans-Prairie had been granted a permit by the Oil and Gas Conservation Board of Saskatchewan to build a line serving the same area, and had actually commenced construction at the time of the hearing. The Province stated that it had granted a permit to construct the pipe line and that it would not consider giving a permit for the transportation of oil from this area to any company other than Trans-Prairie. The Board dismissed Westspur's application and in its Order stated that

"it has concluded that the Applicant's project appears to have certain advantages over the project of Trans-Prairie Pipelines Ltd., but that those advantages are not of such magnitude as to warrant construction of the Applicant's extension where, as would be the case, such construction would either (a), be in duplication of the said Trans-Prairie line if both lines are completed, (which would be uneconomic and unnecessary duplication of pipe lines) or (b), result in abandonment of the Trans-Prairie line which is intended to be completed this

26 (1958), 12 D.L.R. (2d) 215.

80 1952), 68 C.R.T.C. 18.

of (1957): 74, C.R.T.C. 269. 
year, with advantages in that respect, and which has been authorized by the Minister of Mineral Resources of Saskatchewan after a hearing by the Oil and Gas Conservation Board and is actually in course of construction; and that on the whole it is not satisfied that the public interest would be well served by granting the said application under the unusual circumstances shown by the evidence herein -"

As to the Province's submission the Board stated, "it was not made clear to us that Westspur requires the consent of the Oil and Gas Conservation Board of Saskatchewan and that the statements of the Minister of Mineral Resources in that respect have not influenced us in reaching our decision to dismiss the Westspur application."

This case gave rise to much apprehension because while the Board acknowledged its jurisdiction in the matter, conceded advantages to Westspur's proposal, and indicated that Westspur could ignore Provincial requirements, yet it dismissed the application "on the merits", 3 , and on the ground that duplication of oil pipe lines was to be avoided. ${ }^{30}$

In Re Westspur Pipe Line Co. Gathering System, ${ }^{+0}$ decided a year later, the company made an application for approval of a proposal to sell four gathering systems all located within the Province of Saskatchewan, and constructed and operated by Westspur, to its parent company, Producers Pipelines Limited, which was incorporated under the laws of Saskatchewan. All of the facilities were constructed under the approval and jurisdiction of the Board of Transport Commissioners as set forth in the Pipe Lines Act". Section 10 of the Act stated that "A company shall not, without the leave of the Board, . . . sell, convey, or lease to any person its company pipe line, in whole or in part."

The evidence submitted showed the gathering systems were an integral part of the interprovincial undertaking and that none of the oil carried in the gathering systems was consumed in the Province of Saskatchewan. Westspur argued that because of the large volume of oil now handled it was desirable that the operations of the gathering lines become local in character and that upon sale to the provincial company these lines would become a purely local work and undertaking outside the definition of "extra-provincial pipe line" in the Act. Thus Westspur found itself arguing in the face of a Board finding, made on its initial application in 1955 for authorization to construct the lines, that the gathering lines were part of an extra-provincial pipe line and thus part of an interprovincial work and undertaking. It was also taking a position at odds with that taken in the "Extension" case ${ }^{42}$ where it insisted that the extension was part of its interprovincial undertaking.

The headnote summarizes the decision as follows:

"Held, that on the facts the gathering lines could not be held as a matter of law to be local in character. The proposed sale would not result in any real separation of the trunk line business from the gathering line business. The gathering lines, while required for the benefit of the producers, would still be equally required as feeders to the trunk line and would remain an integral part

38 Ibld, p.271, per Wardrope, A.C.C.

39 At the semlnar, Mr. David L. Mathieson of Edmonton clted Canadian Northern Western Rv. Co. v. C.P.R. and (1913), 16 C.R.C. 105, 13 D.L.R. 624, a tascinating rallway parallel to the Extension case. The Alberta Rallway Act and the Railway Act of Canada met squarely, and Beck, $J$. took the vlew that the latter should prevail "all things belng equal". A provinclal rallway and the C.P.R. had each proposed a railway between the same two points, and as each had gone no further than regdstering Its survey. things were "equal" and the C.P.R. won the day.

40 (1957), 76 C.R.T.C. 158 .

11 See tootnoto 28 , ante.

42 see footnote 37, anta. 
of the interprovincial undertaking. The Board could not properly approve a sale to a company that was prohibited by S.10A of The Pipe Lines Act from operating the lines."

The most interesting part of Chief Commissioner Shepard's decision is his discussion of the five factors considered by the Board: "(1) physical connection; (2) ownership; (3) operation; (4) purpose of the gathering lines; (5) whether the gathering lines in question are part of the undertaking of Westspur".43 These factors are dealt with at length in the paper on "The Federal Case" which follows.

\section{Jurisdictional Problems Concerning Pipe Lines IN THE UNITEd STates ${ }^{44}$}

As the United States also has a scheme of federalism, it might be profitable to compare the American situation with that in Canada. As far as pipe lines are concerned, if what follows is not enlightening, there is consolation in this statement by an American writer, G. S. Wolbert, Jr. -

"Despite the richness of literature available on the oil industry in general, the specific subject of pipe lines has remained virtually unexplored." 45

Part of the answer to this paradox appears to be the fact that the matter of pipe lines is so closely bound together with the subject of interstate commerce in oil and gas as commodities that it is more or less impossible to discuss one without the other. In short, the discussion of pipe lines is ancillary to a discussion of interstate commerce whereas in Canada it is possible to treat pipe lines separately.

The various States run the gamut from no pipe line legislation at all to the extreme position taken by the State of Michigan of requiring all pipe lines, including interstate pipe lines, to obtain a Certificate of Public Convenience and Necessity prior to initial construction of the line or any additions to existing lines. Neither this statute nor the few others similar to it have been tested constitutionally in the courts, and to this extent the American situation bears some resemblance to that in Canada.

One significant difference between Canada and the United States is that the State legislatures have in most cases conferred rights of eminent domain on pipe line companies subject to state jurisdiction while Congress has not conferred similar rights on interstate companies. ${ }^{40}$ It is not difficult to imagine the difficulties that interstate companies have in completing a pipe line without powers of expropriation, and thus it is not surprising that they willingly submit to a State authority, as in Michigan, in order to acquire those powers.

In spite of the close relationship between pipe lines and interstate commerce, it is possible to discuss in a limited way interstate oil pipe lines. Under its power to regulate commerce among the various States, Congress enacted the Interstate Commerce Act in 1887." Under that Act crude oil and products ${ }^{\prime \prime}$ pipe lines are regulated by the Interstate

43 See footnote 40, p.177.

11 The author is indebted to Mr. David L. Mathleson of Edmonton for his contribution

45 in addition to Mr. Wolbert's book, the reader is referred to Robert $\mathrm{E}$. Sullivan's in addition to Mr. Pipe Lines [195i] of Oil and Gas Law (New York, 1955).

1 At the seminar it was mentioned in the course of discussion that the U.S. government At the seminar it was mentioned in the course of discussion itsat own name in order to had on occasion exerclsed its powers of eminent domain in its own name in order to acquire the land for an interstate pipe lin

4224 Stat. 379 (1887).

s Common carrler status was extended to products lines as distingulahed from crude oll lunes; 243 I.C.C. 389 (1941). 
Commerce Commission. By the Hepburn Amendment of $1906^{\text {t0 }}$ all interstate lines are impressed with common carrier status. Judicial interpretation has resulted in the Act being given a wide application to all interstate oil lines, including those built over privately-owned rights of way and those which transport only oil owned by the pipe line company. ${ }^{\text {so }}$

The Interstate Commerce Act subjected the pipe line companies to strict regulation, particularly in regard to rates, fares and charges. In earlier times the charges for pipe line transportation were greatly in excess of transmission costs plus a reasonable return on the investment in the pipe line facilities, resulting in extraordinary profits. These charges and profits in turn gave rise to the major legal battles involving oil pipe lines in the early 1940's, with the end result that the return on investment was limited in a way comparable to the regulation of public utilities.

Turning to gas pipe lines, the discussion inevitably involves interstate commerce and proceeds to the Natural Gas Act and the famous Phillips case. $^{\text {B1 }}$ Rather than cover the same ground twice, this subject will be dealt with later in the paper when the American situation regarding regulation of oil and gas as commodities is compared with that in Canada.

\section{REGULATION OF OIL AND GAS AS COMMODITIES}

\section{INTRODUCTORY}

The discussion of this subject will be confined largely to regulation of supply, price and transportation of oil and gas, and to governmental prorationing of production to market demand. Since the extra-provincial movement of oil is relatively unregulated, it will be convenient to refer to gas only. However, with reference to prorationing, it will be more appropriate to refer only to oil as, with some possible exceptions, prorationing is in effect only in respect of oil. ${ }^{.2}$

\section{Provincial Legislation}

Provincial legislation has in its background a factor that has come to have a singular importance-Crown ownership of mineral resources. Ontario and British Columbia have had proprietary jurisdiction since their entry into Confederation, but in the case of the three Prairie provinces the natural resources of the Crown remained under the control of the Federal Government until they were transferred to the provinces under the agreements confirmed by the British North America Act, 1930.83

To the extent that the provinces have proprietary control of their inineral resources, their regulatory position is greatly strengthened because legislation and regulations can be made so much more effective. The extent of ownership in each province, of course, varies, and the variations in turn are the result of historical and geographical factors. Of importance, as well, has been the extent to which the provinces have maintained a policy of granting mineral rights by leases, reservations, or permits rather than by freehold grants. One of the main historical

1034 Stat. 584 (1906).

so In the Matter of Pipe Lines, 24 I.C.C. Rep. 1 (1912). See also The Pipe Lines Cases, 234 U.S. 548 (1914).

s2 Alberta's leglslation on proprationing of gas as well as oll is discussed by John $R$. Ballem in Constltutional Valtity of Provinctal Oll and Gas Legistaltion, (1963). 41 Can. Bar Rev., 205-7.

s8 (Imp.) 21 Geo. 5, c.21; Seo R.S.C. 1952, Vol. VI, p. 219. 
factors was adoption by the Federal Government on October 31, 1887 of the policy of reserving mines and minerals from homestead patents in the prairies.

Alberta has been the principal benefactor both by dint of history and geography. As settlement by homesteaders moved from east to west, there were comparatively fewer homestead patents granted in Alberta in which mines and minerals were not reserved. Geographically, almost all of Alberta lies in the sedimentary basin where most of Canada's oil and gas reserves have been discovered. The result is that Alberta owns the mineral rights in approximately eighty-one per cent of its land area and at the same time is the major source of oil and gas in the country. Thus the factor of ownership takes on added significance for that province and for Canada.

\section{(a) Conservation of Oil and Gas.}

Each of the provinces has extensive, detailed and comprehensive statutes and regulations dealing with conservation." They are all somewhat similar in that they are aimed primarily at the following objectives:

The prevention of waste.

The regulation of the spacing of wells.

Strict control over drilling and production practices.

At this point reference should be made to the decision of the Supreme Court of Canada in Spooner Oils Ltd. v. Turner Valley Gas Conservation Board ${ }^{\text {ss }}$. The Court declared The Turner Valley Gas Conservation Act ${ }^{50}$ to be ultra vires on the ground that the Province had violated a provision of the Alberta Natural Resources Transfer Agreement $^{37}$ so far as existing Dominion petroleum and natural gas leases were concerned. Duff, C.J., in elaborating on this ground, reasoned that if the province had passed the Act prior to the Transfer Agreement, it would have been ultra vires with respect to the lands in the Turner Valley field owned by the Crown in right of Canada since it invaded the exclusive jurisdiction of Parliament with respect to "The Public Debt and Property". At page 644, however, he stated

"As respects tracts of land held in fee simple, totally different considerations apply. Such tracts have ceased to be the public property of the dominion, and in the absence of some dominion enactment relating to matters comprised within the subject of the public property that would have the effect of limiting, the jurisdiction of the provinces (under $5.92(10),(13)$ and (16), there is no ground upon which. such legislation could, as affecting such lands, be held to be ultra vires AMcGregor v. Esquimalt and Nanaimo Ry. Co. (1907) A.C. 462 to 469 )".

The objections of the Court to the Act were later removed in 1938 when the Natural Resources Transfer Agreement was amended to permit the province to affect Dominion Crown leases by conservation legislation. ${ }^{8 B}$ In Alberta, today, there are no longer any Dominion leases in force (and this is likely true in the other Provinces), and so both the

54 B.C.: Regulations under the Petroleum and Natural Gas Act. R.S.B.C. 1960, c.280; Alberta: The Oll and Gas Conservation Act, Alta.p 1957, C.63; Saskatchewan: The O1954, and Gas Conservation Act, R.S.S. 1953, c.327; Man S.166; Ontario: The

so Alta., 1932, c.6.

st This agreement is part of the Britlsh North America Act, 1930, see footnoto 53, anto.

58 Can., 1938, c.36; Alto., 1938, c.14. 
objections of the Court and the $\mathbf{1 9 3 8}$ amendment have lost their significance.

\section{(b) Prorationing of Production}

The Turner Valley Gas Conservation Act ${ }^{30}$ gave the Conservation Board powers to limit the production of wells in order to prevent the enormous waste of residue gas which was then prevalent. Similarly, today's conservation statutes permit controls on production in order to prevent waste and premature dissipation of reservoirs. However, it is easily seen that prorationing of production for conservation purposes is one thing, and prorationing of production to market demand is quite another.

Each of the provinces, except British Columbia, has specific legislation on the latter subject. ${ }^{00}$ Generally speaking, each statute permits the Government or the conservation agency to determine the market demand for oil produced in the Province, to divide the market between the various oil pools in the province, and then to prorate the production in each pool among the several wells. Prorationing has been in effect in Alberta since November, 1950 and Alberta is still the only province to have such a scheme in practice. The Oil and Gas Conservation Board determines the market demand by the "nominations" submitted by the refiners both inside and outside Alberta. The prorationing is done by a rather elaborate system administered by the Bodrd, a feature of which is that each well is permitted a share of the market by giving to it a minimum or "economic allowance"."

\section{(c) Restrictions on Removal of Gas}

Three of the provinces - Alberta, Saskatchewan and Ontario - have made statutory provision to prohibit the removal of gas from the province without a provincial permit. ${ }^{\text {.2 }}$ In the case of Saskatchewan and Ontario, the prohibition consists of a single provision in its conservation statute. In Alberta this matter is dealt with in considerable detail in The Gas Resources Preservation Act, 1956, an Act which originally came into force in 1949 when the supply of gas in Alberta had increased to the point where export appeared certain. Under that Act the Conservation Board has, with the approval of the Government, permitted the export from the province of volumes of gas in excess of 14 trillion cubic feet. According to the most recent figures, the National Energy Board and its predecessor have granted licences to export volumes in excess of 7 trillion cubic feet.

It should also be noted that in Alberta, where almost all of the gas is produced from provincial Crown lands, the government has included in all leases granted after May 15, 1948 the following provision:

"The lessee convenants, and it is an express condition upon which this lease is granted, that natural gas produced from the location shall be used within the Province of Alberta, unless the consent of the Lieutenant Governor in Council to its use elsewhere has been previously obtained. Upon any breach of this to its use elsewhere has becurring whether with or without the consent or knowledge of the lessee, this lease shall forthwith be terminated, shall become

So See lootnote 56, ante.

BO R.S.M. 1954, c.166, and Manitoba Fedulation 14/47, 3.209(B); Ontarlo: R.S.O. 1960. c.122, $8.9(1) 13$.

o1 See footnote 52, ante.

Q2 Alberta: The Gas Resources Preservation Act. 1956. Alta., 1956, c.19; Saskatchewan R.S.S. 1953, c.327, 8.58; Ontario: R.S.O. 1960, c.122, 8.5(11). 
null and void, and shall cease to have any further force or effect, and the rights granted by the lease, freed and discharged from any interest or claim of the lessee or any other person or persons whomsoever claiming by, through or under the lessee, thereupon shall revert to Her Majesty."

The consent of the Lieutenant Governor in Council is given as a matter of course when the lease location is in a field included in a provincial permit under The Gas Resources Preservation Act, 1956.

\section{(d) Regulation of Gas Utilities and Consumer Gas Prices.}

As in the case of conservation statutes, each of the provinces has a comprehensive statute under which the province exercises detailed control over gas utility companies, their undertakings, and the price of gas to ultimate consumers. ${ }^{83}$ Speaking generally, all these statutes contain what are considered to be standard public utility provisions. For our purpose it will be interesting to note the various ways in which the provinces either attempt to limit their jurisdiction or purport to control utilities which might not otherwise comewihin their legislative control.

In British Columbia, the Public Utilities Act in section 3 declares that it applies "only to public utilities that are subject to the legislative authority of the province", and again in section 132 declares that "the purpose and intent of the legislature is to confine the provisions of this Act within the competence of the legislature, and all the provisions thereof shall be construed so as to give effect to this purpose and intent".

In Alberta, The Gas Utilities Act is stated in section 4(1) (a) to apply "to all gas utilities owned or operated by or under the control of a company or corporation that is subject to the legislative authority of the province or that has, by virtue of an agreement with a municipality, submitted to the jurisdiction and control of the Board". However, in section 39 the Legislature prohibits a municipality from granting a gas franchise to any company "the business and operations of which are not subject to the legislative authority of the Province" unless the agreement provides that the company will submit its business and operations to the control and supervisions of the Board "in the same manner and to the same extent as if the company were an owner of a gas utility within the meaning of this Act", i.e., one subject to the legislative authority of the Province.

In Saskatchewan, The Public Utilities Companies Act contains provisions similar to Alberta. Section 3(1) states that Part I applies to "every company incorporated, registered or licenced under any Act of Saskatchewan or carrying on business in Saskatchewan for ... the supply of ... natural gas", and section 47 (1) (e) provides that the Board may refuse to approve a franchise granted by a municipality unless it is satisfied that the franchise provides that "the grantee, purchaser or lessee, his successors and assigns, and the franchise or privilege granted and the works, plant or system sold or leased, shall be subject to all the provisions of this Part".

The Public Utilities Board Act of Manitoba contains provisions which are almost word for word the same as those of its Alberta counterpart quoted above.

63 B.C.: Public Utilitles Act, R.S.B.C. 1960, c.323; Alberta: The Gas Utllitles Act, Alta. 1960, c.37: Saskatchewan: The Public Utillies Companles Act, R.S.S. 1953, c.129, Manitoba: The Public Utilties Act. Man., 1959 (2nd Sess.), c.51; Ontario: The Ontario Energy Boand Act, R.S.O. 1860, c.271. 
The Ontario statute does not contain any provisions similar to those of the other provinces.

\section{(e) Field Prices of Gas}

While all of the provinces regulate consumer prices, only three of them have specific legislation authorizing the control of the price of gas at the well-head or other stages before its delivery to the ultimate consumer.

Under Saskatchewan law, the well-head price alone may be fixed."

In Ontario, the Ontario Energy Board may approve or fix "just and reasonable rates and charges for the sale of gas by transmittors, distributors and storage companies". ${ }^{05}$ No reference is made to the sale of gas by producers, and thus the well-head price is not controlled as such.

In Alberta the price of gas is regulated to a far greater degree than in any of the other provinces. Part I of The Gas Utilities Act ${ }^{06}$ is entitled "Field Prices of Gas" and permits the Public Utilities Board to fix the price of gas at the well-head, at the delivery point of a gas pipe line before or after it is processed, at any point on a gas line, or at a field gathering point. In addition the Board may set the price of gas required to be returned to an underground formation for storage or that has been retained in a formation by order of the Oil and Gas Conservation Board. In a word, the Act contemplates regulation of the price at virtually any and every stage "from the reservoir to the burner tip". In Canada, as in the United States, the further away the gas is from the burner tip the less the price is regulated. In fact, producer prices are not now directly controlled at least as to gas committed to extra-provincial markets.

\section{Federal Legislation}

As indicated previously, the primary source of Parliament's jurisdiction on this subject is found in Head 2 of section 91- "The Regulation of Trade and Commerce". The pertinent legislation is Part VI of The National Energy Board Act. ${ }^{6:}$ This Part regulates exports and imports of gas and prohibits both except under the authority of a licence issued by the Board. Under section 97, the Governor in Council may extend the application of Part VI to oil, but to date no proclamation has been made and there are presently no official indications that it will be made. The extent to which Parliament has legislated with respect to gas is indicated for the most part in subsection (2) of section 82 and section 83 which read:

"82.(2) A license issued under this Part may be restricted or limited as to area, quantity or time or as to class or kind of products."

"83. Upon an application for a licence the Board shall have regard to all considerations that appear to it to be relevant and, without limiting the generality of the foregoing, the Board shall satisfy itself that

(a) the quantity of gas or power to be exported does not exceed the surplus remaining after due allowance has been made for the reasonably foreseeable requirements for use in Canada having regard to the trends in the discovery of gas in Canada; and

(b) the price to be charged by an applicant for gas or power exported by him is just and reasonable in relation to the public interest."

For the purpose of our discussion, attention should be drawn to certain provisions of the National Energy Board Part VI Regulations."

\footnotetext{
64 The Public Utllitles Companies Act. R.S.S. 1953, c.129, s.30

66 The Ontarlo Enerisy Board Act, R.S.O. 1960. c.27i, s.17(1).

6B Alta. 1960, c.37.

67 Sec footnote 30 , ante.

68 SOR /59-435, Canada Gazette, Part II, Vol. 93, No. 21, Nov. 11, 1958.
} 
Section 4 (2), which sets out information to be furnished in an application for a gas export licence, contains in clause (i) a provision in almost identical terms to the one noted in connection with pipe lines ${ }^{\circ 0}$, that is, a requirement to show evidence of having obtained provincial authorization to remove gas from a province if the law of that province so requires. In addition, section 9 of the Regulations makes further tacit reference to provincial legislation such as The Gas Resources Preservation Act, 1956 of Alberta ${ }^{\circ 0}$ by restricting the term of a federal licence to a term not greater than that contained in the provincial permit. Section 9 reads in part:

"9. No export or import licence shall be issued for any period in excess of

(a) twenty-five years from a date to be fixed in the licence,

(b) in the case of a licence for the exportation of gas the removal of which from the province in which the gas is produced is authorized pursuant to a statute of the province, the period during which the removal of gas from the province is authorized, ......

whichever is the lesser."

\section{The Cases}

The remarks regarding the dearth of constitutional cases involving pipe lines apply equally in the case of oil and gas as commodities. There is but one case involving oil and gas specifically in a constitutional issue Spooner Oils Ltd. v. Turner Valley Gas Conservation Board. ${ }^{71}$ While the circumstances which gave rise to that case are no longer present today, the judgment retains some minor importance because the Appellate Division in Alberta and the Supreme Court of Canada rejected the argument that The Turner Valley Gas Conservation Act was invalid as being legislation relating to Trade and Commerce. Duff, C.J. summed the matter up in this way at page 649:

"The statute provides for the regulation of the wells in that area from a point of view which is provincial and for a purpose which is provincial - the prevention of what the legislature conceives to be a waste of natural gas in the working of them. In its substance it deals neither with "trade in general" nor with trade in any "matter of interprovincial concern"; nor is there anything before us to indicate that the working of these mines (excepting, of course, the wells situate upon lands leased from the Dominion) is a matter which, by reason of exceptional circumstances, has ceased to be, or has ever been, anything but a matter "provincial" in the relevant sense."

There are a considerable number of judgments dealing with the Trade and Commerce clause, mostly involving provincial legislation under which the supply, movement and price of a product were regulated under a comprehensive marketing scheme. While judicial thinking on the Trade and Commerce clause appears to be gradually changing and evolving, the cases available provide some excellent analogies for the solution of oil and gas legislation problems and, it is submitted, make the subject less speculative than it might otherwise be.

The speculation today is focussed primarily on the majority judgment of the Supreme Court of Canada in Reference re The Farm Products Marketing Act": decided in 1957. Professor Alexander Smith of the Faculty of Law, University of Alberta, speaks of the judgment as the

\footnotetext{
60 See $p .373$, ante.

7o Alta., 1956, c.19.

is See footnote 11, ante.

i2 See footnote 8 , ante.
} 
"new development";3 and stresses the importance of its implications for the gas industry. ${ }^{74}$ Its importance stems mainly from the judgments given by Kerwin, C.J. Rand, J. and Locke, J. (with whom Nolan J. concurred) which represent the opinion of four of the seven judges in the majority (Cartwright, J. dissented on grounds not material here). In these three judgments there are numerous distinctions made and fascinating examples suggested to demonstrate what might be considered extra-provincial or intra-provincial transactions.

It will be left to the succeeding speakers to argue the implications of the "new development" which, Professor Smith points out, represents a new judicial course similar to that alrady taken by the Supreme Court of the United States in which transactions by themselves intra-provincial may be viewed in terms of a "current", "flow", or "stream" of interprovincial commerce. Professor Smith's argument is that:

"The dominant theme running throughout the decisions is that the nuthority to legislate for the regulation of trade and commerce does not comprehend the power to regulate the contracts of a particular business or trade, or the particular business or trade itself, in a province; or transactions which take place wholly within a province. Now, when it is recalled that sec. 91 (2) has been construed as applying only to interprovincial, international and general trade and commerce, and not to be intraprovincial activity, the restrictive statements above noted, in themselves, are not open to criticism. . . But what we do say is open to criticism, is the judicial finding from time to time that a particular transaction is, in the circumstances, local and not interprovincial. The judicial approach in this connection has been too literal. If a transaction, taken from its context and examined in abstraction, fitted the formula of having taken place wholly within a province then the courts have concluded that the transaction was intraprovincial for the purposes of sec. 91 (2) and therefore beyond the reach of Parliament. But the fact is that a transaction may take place wholly within a province without necessarily being intraprovincial. When a person from Montreal comes to Alberta and purchases a ton of coal, or a cubic foot of natural gas, for shipment to Montreal, it is true that the contract of purchase and sale is made in Alberta but it is not an intraprovincial transaction for the reason that it is an integral part of a larger transaction which involves movement across provincial frontiers and therefore is interprovincial. The judicial tendency, however, has been to examine an event in the abstract and to hold as being local that which if viewed in its factual context would clearly be otherwise. In a word, the courts have refused to look at the facts. This we say has been the judicial tendency in the past. In 1957, however, a majority of the Supreme Court of Canada abandoned the mechanical rigidity of former days and, in embarking on a new line of departure by viewing events in their larger factual context, have independently developed the concept of a "current", "flow" or "stream" of commerce-a concept originally developed by Holmes J. in Swift \& Co. v. United States (1905) 196 U.S. 375, and applied by Taft C. J. in Stafford v. Wallace (1922) 258 U.S. 495 and in Chicago Board of Trade v. Olsen (1923) 262 U.S. 1. The concept in question involves the recognition of the fact that elements, in themselves local, may be integrated into a sequence so as to constitute a current of commerce across provincial boundaries and therefore to come within federal authority".

Since then, the Supreme Court of Canada has continued this trend in Murphy v. C.P.R."s

i3 See appendix to the submission of Trans-Canada Plpe Line Company Limited to the Borden Commission in 1958. This subject is developed in a much broader treatment in Professor Smith's recent book (published since the seminar), The Commerce Power in Canada and the United States (Butterworth's, Toronto, 1963).

it Professor Smlth states: "It would gufflce to substltute the word 'Bns' for 'hogs' wherever the latter appears in the judgments".

75 [1958] S.C.R. 626, 15 D.L.R. (2d) 145. See also Crawford V. Atty.-Gen. for B.C. [1960] S.C.R. 346 . 


\section{Jurisdictional Problems Concerning OIL and Gas In the UnITEd States ${ }^{36}$}

The American reports contain an untold number of decisions where state oil and gas conservation statutes and federal interstate commerce legislation affecting the oil and gas industry have been challenged on constitutional grounds. ${ }^{77}$ The orders of state and federal authorities alike have been and still are challenged in courts as a matter of course - a practice almost unheard of in Canada. The example coming most readily to mind is the multitude of courtroom battles fought prior to the Texas Railroad Commission achieving any real success in upholding state conservation laws.

The history of American regulation is dominated by the tremendous expansion in recent times of the federal government's jurisdiction over the gas industry, which in turn has made serious inroads on the ability of the state governments to make their conservation laws effective. The thought that a parallel situation might develop in Canada leads Canadian lawyers to consider the American law with special interest. In two matters, prorationing and the regulation of gas prices, the constitutional and regulatory framework in the United States provides a background for considering problems which may arise in Canada.

Until recently, prorationing problems in the United States involved oil. It is recognized that prorationing is an essential part of conservation, and that petroleum conservation is primarily a function of state government. A state constitution may specifically empower the legislature to pass laws to conserve petroleum, as the Texas constitution did in 1917. However, it is well recognized that no constitutional provision is needed to support legislation for conservation of petroleum resources. The right exists by virtue of the police power of a state. ${ }^{78}$ Briefly this power may be described as the obligation of the state to protect the rights of each individual in the state from abuses by other citizens. From this premise, the aims of state conservation regulation involve the prevention of waste and the protection of correlative rights. The several states have then adopted, to a greater or lesser degree, various tools of conservation such as prorationing, well-spacing, unitization and the like.

In 1932, the U.S. Supreme Court upheld the Oklahoma Market Demand Law by stating that it prevented physical waste and that any price effect was incidental." However, "hot" oil, that is, oil produced in violation of state conservation orders and sold in interstate commerce, seriously undermined state conservation efforts, and in the summer of 1933 prices hit ten cents per barrel in East Texas. The federal government stepped in and passed the Connally Hot Oil Act in 1935. This statute prohibits the interstate movement of oil that is produced in violation of state law. The constitutionality of the Hot Oil Act was sustained in

70 Apart from the author's Introductory and closing comments and the material on the Phillps case, this section was written by Willam $\mathbf{R}$. SInclalr of Edmonton. The material on the Phillips case was prepared with the assistance of Mr. D. L. Mathleson.

:- The sole Canadian case in which a provincial conservation statute was challenged on the ground that the subject matter came within the Trade and Commerce clause is Spooner Ous Ltd. Y. Turner Valley Gas Conservallon Board, [1933] S.C.R. 629, reversing Spooner Oals Ltd. Y. Turner valicy comment on this aspect of the argument fills about four pases in the decision of the Appellate Dlvislon, and one page In the declsion of Dutf, C.J. In the supreme court.

78 The nature of this power is set out in 12 Corpus Juris 9907.

to Champlin Refining Co. v. Oklahoma Comporation Commitetom, 286 U.S. 210 (1832). 
1936 by the 5th U.S. Court of Appeal ${ }^{\mathrm{so}}$, but it has never been tested before the Supreme Court.

The decision of Railroad Commission of Texas v. Continental Oil Company $^{81}$ in 1941 settled an important question regarding the market demand statute adopted in Texas. Continental demanded that the reasonable market demand for each field in the state should be determined separately and without relation to other fields or to the effect of restricting production in other fields. The Court declared that the state as a whole must be considered, and that the protection of correlative rights requires that all the fields and operators fairly share the burden of any restriction reasonably necessary to prevent waste. The Court further noted that, unless field allowables are based on a prorated state-wide allowable, there is a tendency to build up production materially in excess of the market demand.

Although petroleum conservation is primarily a function of state government, the federal government enters the picture in a number of critical ways. The impact of the Connally Hot Oil Act has been mentioned. The Bureau of Mines of the Department of the Interior plays an important role by publishing forecasts of crude oil production which are used by state agencies in setting production allowables. Further, the Department of the Interior administers the import control program.

So far as gas prorationing is concerned, the principal problem is the protection of correlative rights in fields by careful policing of rateabletake regulations. The most unique gas conservation regulation of this kind has been the attempt to fix minimum wellhead prices for natural gas in certain fields in Kansas and Oklahoma. These regulations were a direct out-growth of long-term contracts. The value of new gas reserves in the fields rose sharply, but much gas was already under contract at low prices. The result was that operators of neighboring wells producing from a common source of supply received vastly different prices for their gas. In 1946, the Oklahoma Commission held hearings and then issued an order for the Guymon-Hugoton Field which provided "that no natural gas shall be taken out of the producing structures or formations of the Guymon-Hugoton Field ... . at a price at the wellhead of less than 7c per thousand cubic feet...". The order was challenged in the courts, but was upheld as a valid exercise of the power of the commission to protect correlative rights in the field. ${ }^{82}$ Recently, however, the courts have held that state price-fixing for gas moving in interstate commerce conflicts with Federal Power Commission jurisdiction over gas producers' interstate sales, and therefore such price-fixing is illegal. ${ }^{\text {s3 }}$

It is apparent that there is a conflict between state conservation regulation and federal regulation of field prices. This conflict is far from over, as states still retain jurisdiction over intrastate sales, and problems of discrimination among producers may arise.

The problem is demonstrated in the recent decision of the United States Supreme Court in Northern Natural Gas Co. v. State Corporation Commission of Kansas. ${ }^{8+}$ Before considering this decision, it is well to

80 Griswotd v. President of the U.S., 82 F. (2d), 922.

82 Cities Service Gas Co. v. Peerless Oll and Gas Co., 340 U.S. 179 (1950)

83 Cities Service Cas Co. v. State Comporation Commission, 355 U.S. 391 (1958).
8. (1863) 83 Ct. 646. 
review briefly the jurisdiction of the federal government with respect to gas prices.

It was not until the advent of natural gas pipe lines spanning the continent that state commissions found themselves running up against a barrier of interstate commerce. The absence of some form of federal regulation created a jurisdictional gap which made the work of state commissions difficult. To bridge the jurisdictional gap, or "no-man's land" as it was called, natural gas was placed under the jurisdiction of the Federal Power Commission in 1938 with the passage of the Natural Gas Act.ss

The jurisdiction of the commission over natural gas has its source in the following provision of the Natural Gas Act:

"1. (b) The provisions of this Act shall apply to the transportation of natural gas in interstate commerce, to the sale in interstate commerce of natural gas for resale for ultimate public consumption for domestic, commercial, industrial, or any other use, and to natural gas companies engaged in such transportation or sale but shall not apply to any other transportation or sale of natural gas or to the facilities used for such distribution or to the production or gathering of natural gas (italies supplied)."

Until the decision in 1954 in Phillips Petroleum Company v. State of Wisconsin et al $l^{\mathrm{si}}$ - the celebrated "Phillips Case" - it had been gen. erally assumed, even by ythe Federal Power Commission itself, that the Commission did not have jurisdiction over independent gas producers who were not engaged in transmission or distribution.

However, it was contended that the Commission's duty to regulate "the sale of interstate commerce of natural gas for resale for ultimate public consumption" could not be effectively exercised with respect to transmission and distribution as long as sales at the production end of the pipe lines were left unregulated. Consequent on the beginning of the Phillips contest, Congress attempted to provide a specific exemption for producers in $1950,{ }^{\mathrm{gT}}$ but the exemption statute was vetoed by President Truman.

In view of the importance of the Phillips case and the ramifications of it in the natural gas industry in the United States, it might be helpful to provide a brief review of the litigation in order to indicate how the jurisdiction of the Federal Power Commission was extended beyond that contemplated by the Commission itself.

In October, $1948^{83}$ the Federal Power Commission directed that an investigation be held to determine:

(1) Whother Phillips was a natural gas company within the meaning of the Natural Gas Act, and if so

(2) Whether any of its rates, subject to the jurisdiction of the Commission, were unjust or unreasonable.

The answers to these questions, in turn, were based on:

(1) Whether the fact of Phillips' sales to five interstate pipe line companies were part of or incident to or activities related to the business of production or gathering, and

85 54 Stat. 821 as amended.

86 347 U.S. 672 (1954).

si The Kerr Bill (1949).

sy F.P.C. Docket No. GLM U8. 
(2) Whether, in fact, regulation of these sales by the Commission would be inconsistent with or conflict with regulation by the three producing states involved - New Mexico, Oklahoma and Texas. ${ }^{80}$

In August, 1951, the Commission came to the conclusion that Phillips' movement and processing of gas and its sales were all part of activities related to its gathering business within the meaning of the gathering exemption of Section 1 (b) of the Natural Gas Act. They also found that rate regulation by the Commission would interfere with state jurisdiction. In view of these findings they did not investigate the reasonableness of Phillips' rates. ${ }^{80}$

This Commission ruling in Opinion 217 was appealed to the United States Circuit Court of Appeals for the District of Columbia." That Court reversed the ruling of the commission and held that the exemption accorded to those producing and gathering gas did not apply and that Phillips was a natural gas company within the meaning of the Natural Gas Act. The Court then held that Phillips' rates were subject to regulation by the Commission.

The Phillips case came before the United States Supreme Court which gave its decision in $1954^{92}$, and, in effect, upheld the judgment of the Circuit Court.

The Supreme Court concluded that the Commission's findings of no jurisdiction were based primarily on the Commission's readings of legislative history and its interpretation of certain decisions of the Supreme Court. It then stated (per Minton, J.):

"We are of the opinion, however, that the finding is without adequate basis in law and that production and gathering, in the sene that those terms are used in paragraph 1(b) end before the sales by Phillips occur."

The majority in the Phillips case held that rates charged by natural gas producers could have a direct and substantial effect on the price paid by ultimate consumers, and that protection of consumers against exploitation at the hands of natural gas companies was the primary aim of the Natural Gas Act.

The clash between state conservation of gas and federal regulation of gas prices in interstate commerce dealt with in the Northern Natural Gas Case ${ }^{93}$ arose when the Kansas State Corporation Commission ordered Northern an interstate pipe line company, to purchase gas rateably from all wells connected with its pipe line system in each gas field within the state. The question at issue was whether this order encroached upon the exclusive regulatory jurisdiction of the Federal Power Commission conferred by the Natural Gas Act.

A Kansas statute empowered the State Commission "to regulate the taking of natural gas from any and all . . . common sources of supply within this state so as to prevent the inequitable or unfair taking from such common source of supply ... . and to prevent unreasonable discrimination ... in favour of or against any producer in any such common source of supply". The State Commission adopted in 1944,

80 Sec Ou and Gas Reports, Vol. 2, p.906.

oo See Docket G 1148, Decision Ausust 16, 1951, Opinion 217.

0192 U.S. App. D.C. 284.

02 Sec lootnote 86, ante.

os Soe footnote 84, ante. 
avowedly as a conservation measure, the basic proration order designed to effect rateable production and to protect correlative rights in the Hugoton Field. In 1959, in order to require Northern to take gas from wells that it had under contract in no higher proportion than from the wells of other producers not under contract, the State Commission entered the order specifically directing Northern to purchase gas rateably from all wells in the field. That order was superseded in 1960 by a general order, directed at all natural gas purchasers taking Kansas gas. These orders presented Northern with the alternatives of complying with the obligations of its original contracts and increasing its take from the other producers' wells - thus taking more gas from Kansas than it could currently use - or of risking liability for a breach of its original contracts by decreasing its take from the wells covered by them below the allowables.

Northern challenged the two orders in the Kansas Courts on the grounds, among others, that they unconstitutionally invaded the exclusive jurisdiction of the Federal Power Commission.

The Kansas Supreme Court, which upheld the State Commission, concluded that the orders constituted only state regulation of the "production or gathering" of natural gas, which is exempted from the federal regulatory domain by the terms of Section 1 (b) of the Natural Gas Act. The majority of the U.S. Supreme Court rejected this contention and held that the orders did not regulate "production or gathering" within that exemption. They said that the terms "production" and "gathering" are narrowly confined to the physical acts of drawing the gas from the earth and preparing it for the first stages of distribution. They held that Northern was not a producer but a purchaser of gas from producers, and none of its activities in Kansas involved "production and gathering" in the sense that those terms are used in Section 1(b).

The Kansas Supreme Court also sustained the orders on the ground that they "in no way involved the price of gas". In rejecting this argument, the U.S. Supreme Court held that the Natural Gas Act precluded not merely direct regulation by the states, but also indirect regulation. The majority emphatically stated that the federal regulatory scheme left no room either for direct state regulation of the prices of interstate wholesales of natural gas, or for state regulations which would indirectly achieve the same result. It held that state regulation must be subordinated to federal regulation when Congress has so plainly occupied the regulatory field.

The principal contention of the State Commission was that rateable taking is essential for the conservation of natural gas, and that conservation is traditionally a function of state power. The Supreme Court did not dispute this contention, but stated that the problem was not as to the existence or even the scope of a state's power to conserve its natural resources; the problem was only whether the Constitution sanctions the particular means chosen by Kansas to exercise the conceded power if those means threaten the federal regulatory scheme. In rejecting this possibility, the majority said that previous decisions of the Court had consistently recognized a significant distinction, which bears directly upon the constitutional consequences, between conservation measures 
aimed directly at interstate purchasers and wholesale for resale, and those aimed at producers and production.

The minority of the Supreme Court held that the rateable take orders were intended as conservation measures which had always been recognized as within state power. They held that the matter was basically a conservation one, and they expressed concern that the decision of the majority would create a rule which, if consistently applied, could well destroy the conservation powers of the states.

The ramifications of this far-reaching decision remain to be seen. Quite conceivably, the current ruling by the majority could be applied so as to nullify virtually any action by a state regulatory commission. Quite conceivably, the Court's ruling could put the Federal Power Commission in the business of issuing rateable take orders, or maybe even per-well allowables. It is interesting to note that the Supreme Court again went beyond the wishes of the Federal Power Commission, because the Commission had proposed that the case be remanded to the Kansas Court to see if that Court could not relieve Northern of its takeor-pay liability. However, the Supreme Court clearly wanted to remove any possible hold the state might have under such an approach, and said that the question is "whether the state order may stand in the face of the pervasive scope of federal occupation of the field".

The regulation of gas prices in the United States presents a conflict between southern and western producers and northern and eastern consumers. As in Canada, the gas rates charged to consumers have been closely regulated almost from the inception of the use of gas as a domestic fuel. On the other hand, the history of the Natural Gas Act and the often erratic role of the Federal Power Commission show how difficult it is to regulate producer gas prices. The most dramatic developments in recent years have been the Supreme Court decision in the Catco case ${ }^{34}$ and the introduction by the Federal Power Commission of the area rate approach to producer regulation ${ }^{03}$.

\section{THE PROBLEM AND THE QUESTIONS}

An examination of the provincial pipe line statutes reveals that the legislatures have not attempted to invide Parliament's jurisdiction over extra-provincial pipe lines. Similarly, the National Energy Board Act contains nothing appearing to invade the provincial authority. Indeed, section 79, which subjects the undertaking of Special Act companies to certain provincial laws, and the requirement in the Board's regulations that an applicant for a gas pipe line certificate comply with a provincial statute prohibiting the removal of gas from a province without a provincial permit, indicate a reluctance on the part of Parliament and the federal government to involve themselves with the provinces on contentious constitutional matters.

O4 Atlantic Refining Co. v. Publie Serv. Comm'n. 360 U.S. 378 (1959).

os Statement of General Polley No. 61-1, 24 F.P.C. 818 (1960) contalns the Commission's proposal and an appendix of rates for twenty-one areas. It was Issued in September. 1960 on the same day that the Commission declded the Phillips rate case which had 1960 on the same day that the Commission decided the Phillips rate case which had consumer "squeeze" is considered In greater detail in the portion of the paper on Provincial-Federal Co-operation entlted "The Amerlcan Experlence" contributed by Professor Thompson, see p. 415, post. See also Nicholas Johnson." "Producer Rate Regulation in Natural Gas Cortification Proceedings: Catco in Contert" (1962) 62 Col. L. Rev. 773 . 
Nevertheless, federal pipe line companies are faced with the general rule that they are subject to the laws of general application of each province and yet need not comply with those provincial laws which might have the effect of frustrating or defeating the construction of a pipe line or interfering with its maintenance and operation. Their undertakings come up against a multitude of requirements which the provinces have power to authorize; for example, provincial laws pertaining to municipal planning, fire regulations, workmen's compensation, boiler and pressure vessel inspection, highway load limit control, to name but a few. These present problems may be regarded as occupational hazards, which the federal companies will likely live with and tolerate.

The question that is raised most often is the constitutional significance of physical connection of a pipe line or gathering system wholly within a province to a pipe line subject to the jurisdiction of Parliament.

It is clear from the railway cases that the courts do not consider the mere fact of physical connection to be conclusive, but will the courts necessarily follow those cases or consider the analogies appropriate? Taking this a step further, if the railway analogy could be adopted for a gas pipe line, would that same analogy be appropriate in the case of an oil pipe line or vice versa? Then there is the further possibility that the courts might be faced with the problem of common management or control-to what extent would the Luscar Collieries:"ase fit the situation?

These questions lead to a further one: If Parliament were found to have jurisdiction over gathering systems connected to extra-provincial pipe lines, to what extent might it exercise legislative authority over the supply and price of oil and gas transmitted by those gathering systems? Is it just another step to extend that jurisdiction back to the well-head itself so that the situation in Canada will parallel that in the gas industry in the United States?

Our experience is that there are roughly two schools of thought among industry and government leaders on the pipe line jurisdictional problem. The one school takes the position that matters should be left as they are and that we should adopt a "wait and see" attitude as far as future judicial decisions are concerned. They point with some justification to the railway companies that have lived with a similar problem since Confederation, have taken each court case as it came, and have managed to survive them all. They feel, generally speaking, that while the Westspur cases have tended to confuse the issue, their importance is over-exaggerated.

The second school finds the result of the Westspur cases so unsettling that they seek legislative solutions such as are suggested in Mr. Lewis' paper on Provincial-Federal Co-operation. They would attempt to fend off the consequences of a decision of the Supreme Court of Canada that would upset the status quo.

Turning to the second problem in this seminar, the critical question is whether Parliament's jurisdiction under the Trade and Commerce clause will be enlarged by the Supreme Court of Canada to give the federal

De Luscar Collieries Ltd. v. MeDonald, [1927] A.C. 925. 
government control over the supply and price of oil and gas back to the gathering systems within provinces, and eventually to the well-head itself, and even, perhaps, to the reservoir.

It is not impossible that the impetus for federal regulation of producer prices may be a political rather than a judicial one. As far as gas is concerned, the elements of a potential producer-consumer price squeeze are present, and the conflict of the interests of western producing provinces and eastern consumer provinces (with heavier population and thus greater representation in Parliament) could lead some future federal government to come forth with legislation to control producer prices of gas sold in interprovincial trade. In 1963 people ponder the possibility because of the similarities between the situation in Canada and that in the United States - the lack of control of producer prices at the outset, the disinclination by the federal authority to regulate gas producers, the obvious difficulty in attempting producer regulation by any method that is fair and does not seriously inhibit the gas industry and investors, the political potency of the provinces having the heaviest concentration of consumers, the public hostility that invariably is aroused by increases in gas prices.

About one thing there is no doubt, and that is the serious concern of the province over the possibility of enlargement of federal jurisdiction. Their stand has been made public in the most unequivocal terms. Typifying the provincial position is the submission concerning natural gas given by the Honourable E. C. Manning, Premier of Alberta, to the Royal Commission on Energy on April 29, 1958. In his concluding remarks Premier Manning recommended the establishment of the National Energy Board and had this to say with respect to what its functions should be and should not be:

"An Energy Board, in our opinion, should have jurisdiction over:

(a) the granting of permits for the construction of interprovincial pipe lines,

(b) the earnings of interprovincial pipe line companies,

(c) The conditions under which an interprovincial pipe line company might be declared a common carrier,

(d) the regulation of interruptible sales of gas supplied through interprovincial pipe lines to ensure that such sales are not adverse to the public interest.

The other major functions of the National Energy Board, in our opinion, should be:

(1) to determine in collaboration with provincial boards, such as the Oil and Gas Conservation Board of Alberta, the Canadian markets which it is economically feasible and in the public interest to supply with Canadian gas.

(2) to determine what gas is surplus to the requirements of such Canadian markets and to approve the export of such gas to foreign markets.

(3) to review all export sales contracts which establish gas prices at the international boundary to ensure that no Canadian gas, entering the United States, is sold at the point of entry at a price which unjustly discriminates against Canadian consumers having regard to load factor and other pertinent circumstances.

It is of equal importance that the powers vested in a National Energy Board should in no case infringe on the jurisdiction of the Provinces and/or on the powers and duties which have been or may be assigned by Provineial Legislatures to provincial boards, such as the Alberta Oil and Gas Conservation Board and the Board of Public Utility Commissioners.

Without attempting to particularize unduly, a National Energy Board should not be empowered to interfere in any way in such fields as:

(a) the regulation or control of production,

(b) the regulation or control of well head or field prices, 
(c) the regulation or control of the transportation of gas or oil within the province, including the regulation and control of transportation rates and charges.

(d) the regulation or control of ultimate consumer prices.

Whenever the public interest requires regulation of these matters, such regulation should be exercised exclusively by provincial boards under the jurisdiction of the legislature of the province concerned."

It has been stated that the federal legislation indicates a reluctance on the part of Ottawa to avoid an intrusion into these spheres of authority which the provinces claim for themselves. It remains to be seen whether Parliament, in spite of its reluctance, finds itself possessed of jurisdiction in these spheres as a result of decisions of the Supreme Court of Canada. If that day comes, solutions may yet be brought about by federalprovincial co-operation in Canada which have so far proved impossible of attainment in the United States. 